\title{
Towards a B2B E-Commerce Evaluation Management Model to Assess Organizational Drivers in Hospitals
}

\author{
Chad Lin \\ Curtin University \\ Curtin Health Research Campus, 10 Selby Street, Shenton Park, WA 6008, Australia \\ elin123au@yahoo.com.au / c.lin@curtin.edu.au \\ Hao-Chiang Koong Lin \\ National University of Tainan \\ 33, Section 2, Shu-Lin Street, Tainan 700, Taiwan \\ Yu-An Huang \\ National Chi Nan University \\ 470 University Road, Puli, Nantou 545, Taiwan \\ Geoffrey Jalleh \\ Curtin University \\ Curtin Health Research Campus, 10 Selby Street, Shenton Park, WA 6008, Australia \\ Ying Chieh Liu \\ Chaoyang University of Technology \\ 168, Jifeng East Road, Wufeng, Taichung, 41349, Taiwan \\ Yueh-Hsia Huang \\ Chinese Culture University \\ 55, Hwa-Kang Road, Taipei, Taiwan \\ Sheng-Hsiung Su, Ching-Ju Chao \\ National University of Tainan \\ 33, Section 2, Shu-Lin Street, Tainan 700, Taiwan
}

\begin{abstract}
Effective utilization of business-to-business (B2B) electronic commerce (e-commerce) in hospitals may lead to many benefits such as increased accessibility to healthcare providers, improved process efficiency, enhanced quality of healthcare services, increased responses to changes, decreased scheduling conflicts, and reduction in administrative costs. However, many hospitals have found that they have not yet fully reaped the expected benefits from their B2B e-commerce investments. Despite this, there has not been much discussion in the literature with respect to the relationship between the organizational drivers on B2B e-commerce benefits for hospitals. Hence, a mixed-method of case study and survey was conducted to examine the relationships between B2B e-commerce benefits, IT evaluation resources allocation, IT investment evaluation methodologies, IT maturity, and user information requirements determination process. A B2B e-commerce evaluation management model was developed to test these relationships. The results provided empirical evidence in support of our proposed model and revealed that hospitals' IT evaluation resources allocation practices mediated the relationship of IT investment evaluation methodologies, IT maturity, and user information requirements determination process with B2B e-commerce benefits. The results also showed that the level of IT maturity had a significant impact on the adoption of IT investment evaluation methodologies.
\end{abstract}

Keywords: hospital, information requirements determination, IT maturity, IT evaluation, B2B e-commerce

Published by Atlantis Press

Copyright: the authors 


\section{Introduction}

Organizations are increasingly relying on business-tobusiness (B2B) electronic commerce (e-commerce) applications to streamline their business processes. ${ }^{1,2,3,4}$ Effective use of B2B e-commerce can assist hospitals to reduce costs in procuring and distributing medicines and other medical-related products to the patients, to procure requisite medical supplies on a $24 / 7 / 365$ basis, to improve business process efficiency, and to provide accurate and timely business information and streamline orders and payments. For example, the use of ecommerce technologies in conjunction with videoconferencing equipment enables hospitals and other healthcare organizations to procure their products more effectively and efficiently via online detailing with pharmaceutical companies. ${ }^{5,6,7}$ A survey conducted by Institute for Information Industry estimated that the investments in B2B e-commerce by Taiwanese enterprises increased by $8.4 \%$ between 2008 and 2009 and it is likely to increase to more than US\$340 billion by $2013 .^{8}$

The management of IT/B2B is a challenging task with many projects failing to achieve their intended objectives. $^{9,10,11,12,13,14,15,16,17}$ In fact, many senior hospital executives have discovered that they have not yet fully reaped the benefits from their B2B ecommerce investment. Research studies have continued to debate whether productivity benefits of spending in IT for healthcare have been overstated. ${ }^{18,19}$ The relationship between the use of IT in healthcare and the slowdown in productivity became known as "IT productivity paradox" and the term has gained increasing notoriety as researchers continue to argue whether the investments in healthcare IT was worthwhile. $^{20,21,22}$ Some researchers take the position that the confusion over the realization of $\mathrm{B} 2 \mathrm{~B}$ ecommerce benefits is due to, among other things, low level of organizational IT maturity (hereafter referred to as IT maturity) and lack of use of IT investment evaluation methodologies. ${ }^{23,24,25}$ In addition, despite the focus by recent literature of the role played by the IT investment evaluation methodologies and the importance of other organizational drivers (e.g. the levels of IT maturity, allocation of appropriate and sufficient IT evaluation resources (hereafter referred to as IT evaluation resources allocation), and user information requirements determination process) on B2B e-commerce benefits remain unclear. ${ }^{24,26}$ For example, Hackbarth \& Kettinger and Lin et al. have found that there was some connection between organizational IT maturity and IT investment evaluation. $^{27,28}$ Melville et al. have pointed out that allocation of appropriate IT evaluation resources is somewhat linked with successful adoption of IT investment evaluation methodologies. ${ }^{29}$ There is also some evidence to suggest that organizations with high levels of IT investment evaluation may lead to higher level of B2B e-commerce benefits. ${ }^{30,31,32}$

Despite this, there has not been much discussion in the literature with respect to the relationship between these organizational drivers on B2B e-commerce benefits. In fact, very few B2B e-commerce studies have been conducted in the healthcare area ${ }^{33,34,35,36}$ and most of these studies deal with strategic marketing of ehealth services and systems ${ }^{37}$, customer relationship management ${ }^{38}$, and initial designing stage of efulfillment systems $^{39}$. In particular, IT investment evaluation and the organizational drivers affecting the realization of B2B e-commerce benefits in Taiwanese hospitals remain poorly understood and relatively under-researched. Given the financial stakes involved, better understanding of the implication of B2B ecommerce investments and their relationships with IT investment evaluation methodologies and the abovementioned organizational drivers in Taiwanese hospitals is warranted. Hence, a mixed-method of case study and survey was conducted to examine the relationships between IT investment evaluation methodologies and other organizational drivers identified during the case study phase and their impact on the B2B e-commerce benefits. The main objectives of this study were to: (1) develop a B2B e-commerce evaluation management model; and (2) test the relationships between B2B ecommerce benefits, IT evaluation resources allocation, IT investment evaluation methodologies, IT maturity, and user information requirements determination process.

\section{Theoretical Background}

Two different perspectives, production economics and organizational perspectives, form the basis for this 
study. The production economics perspective establishes a direct connection between IT investment evaluation practices and B2B e-commerce benefits whereas the organizational perspective conceptualizes the linkage between technology adoption and diffusion and B2B e-commerce benefits realized. The production economics perspective views organizational activities as economic production processes ${ }^{40}$. In these processes, input factors such as the adoption of IT investment evaluation methodologies can assist in transforming B2B e-commerce investments into outputs such as B2B e-commerce benefits. Previous studies have shown that organizations that adopt IT investment evaluation methodologies can achieve better business performance or benefits. ${ }^{29,41,42}$ For example, the adoption of IT investment evaluation methodologies serve as an essential studying tool for organizations and it assists in gathering support from key stakeholders. ${ }^{43,44,45}$ It also helps to underscore best practices which organizations can apply lessons learnt to future B2B e-commerce investment processes and this has a significant impact on organizations' B2B e-commerce benefits from. ${ }^{29,46,47}$ This is important as the use of IT investment evaluation methodologies assists organizations to focus on all aspects of a B2B e-commerce investment at regular intervals in order to evaluate realized benefits against their original objectives and to initiate corrective action. $42,48,49,50,51$

However, the adoption of IT investment evaluation methodologies is a complex process for most organizations. ${ }^{52,43,54}$ Several studies have revealed that many organizations fail to adopt IT investment evaluation methodologies. ${ }^{41,42}$ This indicates that organizations need to consider not just the production economic perspective but also the organizational perspective when investing in $\mathrm{B} 2 \mathrm{~B}$ e-commerce. The organizational perspective can be useful to view the contribution of the organizational drivers in eliminating or minimizing the barriers of adopting IT investment evaluation methodologies. The technology adoption and diffusion theory stipulates that various kinds of barriers will eliminate or minimize the benefits of an IT investment (e.g. B2B e-commerce). The Limits-toValue model proposed by Chircu and Kauffman ${ }^{55}$ stated that there are many technology adoption barriers which can prevent organizations in realizing benefits from their B2B e-commerce investment. The technology adoption and diffusion theory highlights the need for organizations to eliminate or minimize the adoption barriers by, for instance, increasing the level of organizational IT maturity, the level of complete and accurate user information requirements determination process, and by allocating appropriate IT evaluation resources. This will greatly assist hospitals in successfully adopting the IT investment evaluation methodologies as well as in realizing the expected B2B e-commerce benefits.

\section{Research Hypotheses}

\subsection{IT investment evaluation methodologies and B2B e-commerce benefits}

Hospitals generally have very poor understanding of the importance of their B2B e-commerce adoption and implementation. ${ }^{56}$ Empirical studies in this aspect have also been scarce in the literature ${ }^{57,58,59,60}$ particularly in the healthcare area. ${ }^{33,35,61}$ The use of B2B e-commerce by healthcare and other organizations includes online activities such as transactions between themselves and their suppliers and the sales of products and services via e-marketplace. ${ }^{56,62,63}$ It enables hospitals to minimize their procurement costs and assists their suppliers to sell via an efficient marketing channel. ${ }^{56} \mathrm{~B} 2 \mathrm{~B}$ e-commerce also allows hospitals' business partners to access their internal business systems via the Internet. Moreover, it facilitates hospitals to efficiently position their organizational procurement structures (ie. insourcing or outsourcing) by seeking alternative product and service suppliers via B2B marketplace. ${ }^{64}$

Hospitals must look at B2B e-commerce from a strategic perspective and evaluate its benefits because it can assist them in developing and controlling strategic, tactical, and operational plans that define the appropriate role of $\mathrm{B} 2 \mathrm{~B}$ e-commerce in their organization. ${ }^{65}$ In addition, the evaluation and benefits realization mechanisms can expedite the organizational learning process and help make B2B work to the benefit of all customers and external partners, whether viewed from a narrow buyer/seller perspective or a broader supply chain perspective. ${ }^{65,66,67}$

In order to keep abreast of changing requirements, organizations require new metrics to evaluate whether their B2B e-commerce investments are paying off. ${ }^{68}$ This is crucial given the effective leverage and evaluation of B2B e-commerce investments can assist 
organizations to realize their expected B2B e-commerce benefits. $^{69,70}$

However, despite the high expectations for the benefits from B2B e-commerce in hospitals, its evaluation issues and processes remain poorly understood and relatively under-researched. ${ }^{71,72}$ Factors contributing to low adoption vary and one important factor is the inability by hospitals to evaluate the business value of their B2B e-commerce investments as well as to ensure that the expected benefits are eventually realized or delivered. ${ }^{73,74}$ Evaluation of B2B e-commerce in hospitals is not straightforward and can be confusing and problematic due to its complexity. 73,75,76 The less precisely bounded environment of B2B e-commerce technology adds more complexity to the traditional IT measurement problem as this type of investment is physically distributed between suppliers and vendors, making the evaluation process even more difficult. ${ }^{77,78,79}$ The problem becomes more evident as B2B e-commerce is used to link the supply chain or to change the structure of industries, since costs and benefits have to be tracked across functional and organizational boundaries. $^{48,80}$

There are several IT investment evaluation methodologies (e.g. Five-step Evaluation Process, ${ }^{75}$ Health Technology Assessment, ${ }^{81}$ System Development Stage, ${ }^{82}$ and The $4 \mathrm{Cs}$ (communication, care, control, and context) Framework ${ }^{83}$ ) that can be used to evaluate B2B e-commerce investments in hospitals. Relevant IT evaluation research indicates that organizations using appropriate IT investment evaluation methodologies may result in higher level of B2B e-commerce benefits. $29,73,84$ On the basis of the relevant literature reviewed, it is hypothesized that:

H1: The adoption of an IT investment evaluation methodology has a positive effect on B2B e-commerce benefits.

\subsection{IT maturity, IT investment evaluation methodologies, and IT evaluation resource allocation}

The revised stages of growth model by Galliers and Sutherland ${ }^{85}$ was used in this study to examine the level of IT maturity within the survey respondents. IT maturity refers to an organization's capability to utilize its existing IT processes and components to obtain business value. ${ }^{85,86,87}$ It is pertained to the organization's ability to effectively deploy IT towards the achievement of B2B e-commerce benefits. ${ }^{88}$ The level of IT maturity is critical in assessing IT projects and is linked with the ability of an organization to adopt and implement processes and methodologies. ${ }^{27}$ It is also about the balance between the IT being adopted, and the capabilities as well as management processes used to master and utilize IT within the organization. ${ }^{89,90}$ Organizations are more capable to track and manage user information requirements of the proposed IT systems once sufficient organizational IT maturity in both processes and technology has been achieved. ${ }^{91,92}$ In addition, these maturity models extend organizations' abilities to evaluate and track impacts of IT investments such as B2B e-commerce initiatives within their organizations. ${ }^{92}$ It relates to the result of a history of IT performance assessment and modifications which can lead to improved management processes as organizations mature. ${ }^{93,94}$

The level of IT maturity may affect the adoption of IT investment evaluation methodologies which can be used as the tools to evaluate the functionality required in a proposed IT system. ${ }^{85,95}$ Findings from a study of an Electronic Medication Management System in a major public hospital reveal that effective evaluation of a system requires appropriate level of IT maturity and a deep understanding of its nature and complexity. ${ }^{96}$ Organizations which have place more emphasis on increasing their IT maturity are more likely to conduct evaluation. ${ }^{97}$ Therefore, on the basis of the relevant literature reviewed, and specifically with respect to the adoption of IT investment evaluation methodologies, it is hypothesized that:

H2: The level of IT maturity has a positive effect on the adoption of an IT investment evaluation methodology.

According to Grant ${ }^{98}$, an organization's productivity and its ability to compete stem mainly from the valuable resources it possesses. These resources can take a variety of forms including core competence and capabilities, both in physical and intangible shapes. Amit and Schoemaker ${ }^{99}$ point out that the organizational resources can take forms of enterprise knowledge, financial resources, physical assets, and manpower. In addition, resources are tradable and can be used to engage the resources within the organization, such as implicit processes to transfer knowledge within 
the organization. ${ }^{15,100}$ A resource is capable of assisting an organization in gaining a competitive advantage by, for example, formulating a value-creating strategy in order to outperform its competitors or to reduce its own weaknesses. ${ }^{99,101,102}$ Chircu and Kauffman ${ }^{55}$ have found that organizations need to possess sufficient capabilities to allocate resources as well as to identify and assess a number of industry-independent sources of benefits. We argue that hospitals can only take necessary steps to eliminate barriers to the allocation of IT evaluation resources when they increase their level of IT maturity. Thus, the following hypothesis is derived:

H3: The level of IT maturity has a positive effect on the allocation of IT evaluation resources.

\subsection{IT investment evaluation methodologies, IT evaluation resource allocation, and $B 2 B e$ - commerce benefits}

Allocation of appropriate and sufficient IT evaluation resources is critical for the success of $\mathrm{B} 2 \mathrm{~B}$ e-commerce initiatives. $^{88,102,103,104}$ Chircu and Kauffman ${ }^{55}$ have argued that organizations need to possess appropriate and sufficient resources and capabilities to evaluate benefits. In order to determine the potential B2B ecommerce benefits for a specific industry and/or a specific organization, the contribution of all the benefits need to be evaluated during the B2B e-commerce evaluation process. ${ }^{55}$ However, this process is fraught with industry and organizational constraints that can determine the amount of realized B2B e-commerce benefits. ${ }^{55}$ Organizations need to allocate appropriate IT evaluation resources in order overcome as many evaluation constraints as possible in order to obtain maximum $\mathrm{B} 2 \mathrm{~B}$ e-commerce benefits.

Ayal \& Rothberg ${ }^{105}$ have pointed out that resources usually encompass manpower, services, and hardware resources and capabilities. Chircu and Kauffman ${ }^{55}$, on the other hand, have argued that failures of adoption of IT investments were often due to resource constraints which were largely caused by the inability of an organization to obtain necessary enough up-to-date IT evaluation resources. The resources allocation can affect an organization's ability to undertake evaluation as well as to realize the expected B2B e-commerce benefits. The allocation of sufficient IT evaluation resources plays a key role in these processes as past studies have shown the positive link between IT investment evaluation methodologies and allocation of appropriate and sufficient IT evaluation resources. ${ }^{106,107,108,109,110,111}$ We argue that hospitals need to undertake IT investment evaluation methodologies to determine the appropriate level of valuable and scarce IT evaluation resources needed within the organization to realize the expected B2B e-commerce benefits. Thus, the following hypotheses are derived:

H4: The adoption of IT investment evaluation methodologies has a positive effect on the allocation of IT evaluation resources.

H5: Allocation of IT evaluation resources has a positive effect on the realization of B2B e-commerce benefits.

\subsection{Information requirement determination and IT evaluation resources allocation}

The user information requirements determination process is a critical phase within any system development life cycle. It relates to an organization's capability to determine its own requirements. The user information requirements determination process has generated a lot of interest and debate among researchers and practitioners as a potential means for improving the success rates of IT investments. ${ }^{112,113,114}$ The user information requirements determination process was defined by Browne and Ramesh ${ }^{95}$ as "a set of activities used by a systems analyst when assessing the functionality required in a proposed system" (p. 625). It has become increasingly important in obtaining the correct and complete set of user requirements in developing of any IT or B2B e-commerce projects. However, with today's rapid changes of technology and customer driven environments and needs, user information requirements determination process has become increasingly difficult for organizations to elicit and predict. ${ }^{115}$ This difficulty can result in interpersonal conflict among stakeholders since system users desire changes to reflect environmental changes whereas IT professionals desperately need to lock-in requirements so that the project or contract can be delivered within budget and on time. ${ }^{113}$ This in turn can lead to poor allocation of IT evaluation resources or any other types of resources. Thus, the following hypothesis is derived:

H6: The user information requirements determination process has a positive effect on the allocation of IT evaluation resources. 


\section{Research Methodology}

A universal National Health Insurance scheme in Taiwan was officially launched in 1995. However, due to the financial difficulties within the national health care system, the costs and revenue of these hospitals and healthcare providers have been closely monitored by the Bureau of National Health Insurance. ${ }^{107,116}$ The Bureau of National Health Insurance's fixed-budget policy has resulted in reimbursement prices that made many hospitals unsustainable. That is, the payments to hospitals, have been decreasing markedly each year while, at the same time, their costs have been increasing rapidly. The reimbursement prices by the Bureau of National Health Insurance are among the lowest in the world. ${ }^{117}$ Under the twin pressures of Bureau of National Health Insurance reimbursement price constraints and the intense competition in the healthcare marketplace, the total number of hospitals in Taiwan has decreased by more than $30 \%$ (from 835 to 530 ) between 1986 and 2007. ${ }^{117,118,119}$ Most hospitals have strategies in place to attract and win market share by connecting with other healthcare providers and businesses and by investing in B2B initiatives in order to provide quality and personalized care for their patients. The current roles of most Taiwanese hospitals are to focus on meeting their patient needs as well as to reduce their operating costs via the efficient use of their existing infrastructure and investments (e.g., B2B initiatives).

However, despite most Taiwanese hospitals are beginning to look for ways to realize benefits from their IT and B2B e-commerce investments, many of them simply do not evaluate their B2B e-commerce investments to confirm whether the expected benefits are actually realized. Hence, the main objectives of this study were to: (1) develop a B2B e-commerce evaluation management model; and (2) test the relationships between $\mathrm{B} 2 \mathrm{~B}$ e-commerce benefits, IT evaluation resources allocation, IT investment evaluation methodologies, IT maturity, and user information requirements determination process. These needed both: (a) a broad overview of such environments obtained from a smaller number of hospitals (case study); and (b) a detailed examination of these issues and relationships collected from a large number of hospitals (survey). Eisenhardt ${ }^{120}$ argues that multiple data collection methods and sources provide stronger substantiation of constructs and hypotheses, strengthening convergence of results. Mingers 121 indicates that mixed-method research results will be richer and more reliable. In addition, the use of both qualitative and quantitative data can be used to construct theoretical models ${ }^{122,123}$ such as the B2B e-commerce evaluation management model. Therefore, a mixedmethod (and paradigm) approach was taken in combining case study and survey.

\subsection{Case study}

IT managers and executives from twenty-seven Taiwanese hospitals were interviewed. The cases were deliberately chosen in order to focus efforts on theoretically useful cases (following the theoretical, nonrandom sampling strategy by Eisenhardt ${ }^{120}$ ). The hospitals in Taiwan are accredited by Department of Health into three levels: medical centers (Level 3), regional teaching (Level 2) hospitals, and district (Level 1) hospitals. Hospitals which are classified as "medical centers" generally have more than 800 beds and are affiliated with a medical school. District hospitals are usually the smallest hospitals while the size of regional teaching hospitals are usually somewhere between Level 3 and Level 1 hospitals. In total, two of the interviewed hospitals were medical centers, nine were regional teaching hospitals, and sixteen were district hospitals. Eleven of these were public hospitals where the other nine were private hospitals. The remaining seven were not-for-profit hospitals.

The case study method enables the researcher to examined how Taiwanese hospitals evaluate their B2B ecommerce investments and to what extent their B2B ecommerce benefits are realized. The questions asked during the interviews included the practices and processes of $\mathrm{B} 2 \mathrm{~B}$ e-commerce evaluation and benefits realization and their impact on $\mathrm{B} 2 \mathrm{~B}$ e-commerce benefits, IT evaluation resources allocation, the user information requirements determination process, and user satisfaction in Taiwanese hospitals, as well as other B2B e-commerce adoption and IT outsourcing issues. Qualitative content analysis was then used to analyze the data from the case study. ${ }^{124}$ The researchers evaluated the responses from the interviews and classified them according to the research themes. The analysis of the case study results was conducted in a cyclical manner and the results were checked by other experts in the field. 
The external experts were asked to trace the logical flow of the research study, research questions, case findings and analysis and identification of constructs and thereby identifying any gaps in the chain of evidence. ${ }^{125}$ The findings from these information gathering approaches were analyzed iteratively by the researchers on an individual level, differences reconciled and then a judgment made on each of the major themes. Questions relating to a particular research theme, for example, level of B2B e-commerce benefits, were examined as a cluster. Divergent views within the same hospital were assessed in terms of the relative strength of the perspective according to the numbers of responses falling in particular categories. This was done as a form of in-case analysis and to develop general explanations and interpretations. $^{120}$ These steps enhance the construct validity, reliability and overall quality of the research. ${ }^{125}$

\subsection{Survey}

Prior to determining the sample size for the survey, a pilot survey of IT managers of 10 hospitals was conducted. Some valuable feedback was received and the questionnaire was slightly adjusted for the main survey. For the main survey, questionnaires were randomly sent to 350 hospitals in Taiwan from a list obtained from the Ministry of Health and Welfare. Two follow-up mailings or phone calls were carried out to increase the response rate. A total of 114 samples were returned but 7 of these either were incomplete or had no B2B e-commerce systems and therefore, were discarded. In the end, a total of 107 complete and usable responses were obtained. The potential problems inherent in a survey make the analysis of nonrespondents a crucial exercise in order to avoid non-response bias. ${ }^{126}$ One of the key assumptions in such an approach is that later respondents to a survey are more similar to nonrespondents than are earlier respondents. ${ }^{127}$ An ANOVA analysis was performed to compare late returns with earlier responses in order to check for non-response bias. ${ }^{127}$ No significant differences were detected between the two samples on total number of employees.

Of these respondents, 39 (36.4\%) were public hospitals while $22(20.6 \%)$ were private hospitals. The remaining $46(43.0 \%)$ were non-for-profit hospitals. Approximately a third $(39,36.4 \%)$ of these hospitals were located in Southern Taiwan and 31 (29.0\%) were located in Central Taiwan. Just under a quarter (23,
$21.5 \%)$ of the responding hospitals were from Northern Taiwan and the remaining 14 (13.1\%) were from Eastern Taiwan.

\subsection{Measures}

Respondents were asked to indicate their agreement on a 7-point scale (1 for strongly disagree and 7 for strongly agree) with statements concerning five main constructs: (1) IT maturity; (2) IT investment evaluation methodologies; (3) IT evaluation resources allocation; (4) user information requirements determination process; and (5) B2B e-commerce benefits. Reliability analysis (alpha) was conducted on these five main constructs.

The IT maturity scale was based on Galliers and Sutherland's Revised Stages of Growth Model. ${ }^{85}$ This scale assesses a hospital's capability to utilize its existing IT infrastructure to obtain business value. The scale was revised into a six-item measurement. The alpha value for this scale was 0.86 , indicating acceptable values of internal consistency. ${ }^{128}$ This scale measured the organisational IT maturity of an organisation in terms of its stage of growth for each of the six elements strategy, structure, systems, style, skills, and overall goals.

The IT investment evaluation methodologies scale was derived from Ward et al., Lin and Pervan, and Ward and Daniel. ${ }^{129,130,131}$ The scale measured the use of IT investment evaluation methodologies of hospitals investing in $\mathrm{B} 2 \mathrm{~B}$ e-commerce investments. This scale has eight items and alpha value was 0.96 . The scale measured the usage, wide use, processes taken to identify, review, and evaluate the $\mathrm{B} 2 \mathrm{~B}$ e-commerce projects.

The IT evaluation resources allocation scale was mainly derived from Chircu and Kauffman and Lin et al. 55,132 The scale measured the spending on, management of, and allocation of various B2B e-commerce related resources in the hospital. The scale has six items and the alpha value for this scale is 0.88 .

The user information requirements determination process was mainly derived from Moody et al. and Lin and Lin. ${ }^{133,134}$ The scale measured the usage and effectiveness of user information requirements determination process during the implementation of the B2B e-commerce projects for the participating hospitals. The scale has four items and the alpha value for this 
scale is 0.85 .

The $B 2 B$ e-commerce benefits scale was derived from scales used by Lin et al., Kao, and Teo and Ranganathan. ${ }^{78,135,136}$ The scale has eight items and the alpha value for this scale is 0.94 . The scale measured the benefits (i.e. corporate images enhancement, increased sales, and cost reductions) obtained through the adoption of B2B e-commerce. In the absence of objective data on B2B e-commerce benefits, the IT executives' perceptions were used. Although there has been some debate regarding the legitimacy of perceptual measures as a proxy for objective measures of B2B e-commerce benefits, research has succeeded in alleviating some of the concerns by showing that perceptual measures of organisational performance has a strong positive relationship with more traditional objective measures. ${ }^{42}$ For example, a study by Venkatraman and Ramanujam 137 showed that there was a high degree of correlation between perceptual and objective performance measures in the process of measuring performance of several competing organisations. This reflects the degree of experience of IT executives and their constant involvement in the IT investment process. ${ }^{138}$ Indeed, several studies have shown that IT executives' perceptions are critical to understanding how IT affects the performance of organisations. ${ }^{139,140,141}$

\section{Research Findings}

\subsection{Case study}

Key issues identified during the case study phase were: IT investment evaluation methodologies, IT maturity, IT evaluation resources allocation, user information requirements determination process, and $\mathrm{B} 2 \mathrm{~B}$ ecommerce benefits. These issues were examined as research constructs in more details in the survey section.

\subsection{Survey}

Prior to analysis, data was screened for possible outliers, and missing or out-of-range values. All measures were then analyzed for reliability and validity in accordance with the guidelines set out by Jöreskog and Sörbom ${ }^{142}$. The reliability of these constructs was evaluated using Cronbach's coefficient alpha $(\alpha)$ and their $\alpha$ values were all above 0.80 , indicating a reliable measurement instrument. ${ }^{128}$ In addition, three types of validity were assessed to validate our measurement model: content validity, convergent validity, and discriminant validity. Content validity was established by ensuring consistency between the measurement items and the extant literature. This was done by interviewing IT managers and pilottesting the instrument before sending out the main survey. Churchill ${ }^{143}$ has suggested that convergent and discriminant validities should be examined for construct validity. Therefore, we assessed convergent validity by examining composite reliability (CR) and average variance extracted (AVE) from the three constructs. ${ }^{144}$

Our CR values of the five constructs were between 0.80 and 0.95 and all are above the suggested minimum of $0.70 .^{144}$ Their AVE values were all above 0.60 and these values provided further evidence of convergent validity. ${ }^{145}$ These AVE values could also be used to assess discriminant validity which was evident in the results of this study as AVE values for all constructs were higher than the largest squared pairwise correlation between each construct. ${ }^{145,146}$

SPSS and AMOS were then used to analyze the data. SPSS was used initially to obtain some descriptive data and SEM (Structural Equation Modelling) using AMOS was then applied to estimate direct and indirect effects for the model. A two-step SEM approach was followed to first evaluate the quality of the measurement items and then estimated the structural model. ${ }^{146}$ All variables within the model were regarded as separate reflective measures. The model was run as a structural model. It was found that the direct path between "IT investment evaluation methodology" and "B2B e-commerce benefits" (H1) was weak and not significant and so was removed from the proposed model. The final model (Figure 1) had achieved a good fit of the data and the resulting fit indexes indicated that the measurement model fitted the data well: $\chi 2=213.91$ (171 degrees of freedom), $\mathrm{p}=0.32$, comparative fit index $(\mathrm{CFI})=0.98$, root mean square error of approximation (RMSEA) = 0.04, and Goodness-of-Fit Index (GFI) $=0.90$.

The value of (Chi-square/degree of freedom) is less than 3 and the GFI is above $0.90(\mathrm{GFI}=0.93) .{ }^{144,148} \mathrm{In}$ addition, the RMSEA value is less than 0.05 , implying good model fit. ${ }^{149}$ Moreover, the ranges of all factor loadings and the measurement errors were acceptable and significant at alpha $=0.01$, which provided evidence of convergent validity. 


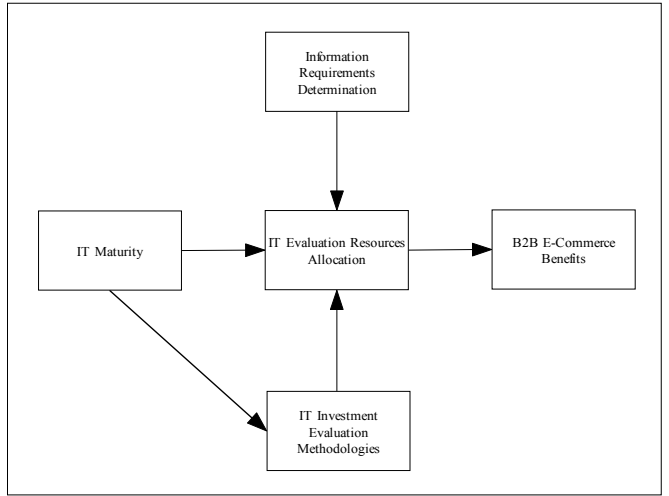

Fig. 1. The B2B e-commerce evaluation management model

The level of IT maturity was positively related to the adoption of IT investment evaluation methodologies $(\beta=$ $0.39 * * *)$. This suggests that the level of IT maturity had a significant impact on the effective use of IT investment evaluation methodologies. This provides full support for H2. H3, which predicted that hospitals' level of IT maturity could affect their ability to allocate IT evaluation resources, was partially supported $(\beta=$ $\left.0.26^{*}\right)$. As anticipated, both the adoption of IT investment evaluation methodologies and the user information requirements determination process were positively related to the hospitals' ability to allocate IT evaluation resources which in turn had a significant impact on the realization of $\mathrm{B} 2 \mathrm{~B}$ e-commerce benefits ( $\beta=0.41^{* * *}, \beta=0.47^{* * *}$, and $\beta=0.62^{* * *}$, respectively). This provided support for H4, H5, and H6.

Table 1. The six proposed research hypotheses

\begin{tabular}{|l|l|l|}
\hline & Hypotheses & Supported? \\
\hline H1 & $\begin{array}{l}\text { The adoption of an IT investment } \\
\text { evaluation methodology has a positive } \\
\text { effect on B2B e-commerce benefits. }\end{array}$ & No \\
\hline H2 & $\begin{array}{l}\text { The level of IT maturity has a positive } \\
\text { effect on the adoption of an IT } \\
\text { investment evaluation methodology. }\end{array}$ & Yes \\
\hline H3 & $\begin{array}{l}\text { The level of IT maturity has a positive } \\
\text { effect on the allocation of IT evaluation } \\
\text { resources. Partially }\end{array}$ & $\begin{array}{l}\text { The adoption of IT investment } \\
\text { evaluation methodologies has a } \\
\text { positive effect on the allocation of IT } \\
\text { evaluation resources. }\end{array}$ \\
\hline H5 & $\begin{array}{l}\text { Allocation of IT evaluation resources } \\
\text { has a positive effect on the realization } \\
\text { of B2B e-commerce benefits. }\end{array}$ & Yes \\
\hline H6 & $\begin{array}{l}\text { The user information requirements } \\
\text { determination process has a positive } \\
\text { effect on the allocation of IT evaluation } \\
\text { resources. }\end{array}$ & Yes \\
\hline
\end{tabular}

\section{Discussion}

To examine the impact of IT investment evaluation methodologies and three organizational drivers on B2B e-commerce benefits in Taiwanese hospitals, this study developed B2B e-commerce evaluation management model. IT maturity was found to have a significant positive impact on the adoption of IT investment evaluation methodologies which, in turn, had a significant effect on the allocation of IT evaluation resources. The results also revealed that an accurate and complete user information requirements determination process was positively related to the allocation of IT evaluation resources. These, in turn, also had a significant positive impact on the realization of B2B ecommerce benefits. In addition, the results showed that the level of IT maturity had a partial impact on the hospitals' ability to allocate IT evaluation resources. However, the adoption of IT investment evaluation methodologies alone did not have significant impact on the realization of $\mathrm{B} 2 \mathrm{~B}$ e-commerce benefits. The adoption of IT investment evaluation methodologies had only an indirect impact on the hospitals' B2B ecommerce benefits, depending on its ability to requisite IT evaluation resources. These results have provided a number of insights and implications.

First, Taiwanese hospitals' ability to allocate the requisite IT evaluation resources appears to have a mediating effects on the relationships between other organizational drivers (i.e. IT investment evaluation methodologies, IT maturity, and user information requirement determination process) and the realization of B2B e-commerce benefits. The results also reveal that those hospitals which had adopted IT investment evaluation methodologies alone could not produce B2B e-commerce benefits. In other words, these organizational drivers must be used by hospitals in conjunction with sufficient requisite IT evaluation resources to be able to realize any $\mathrm{B} 2 \mathrm{~B}$ e-commerce benefits. Second, hospitals' level of IT maturity played a significant role in dictating the use of IT investment evaluation methodologies which in turn led to allocation of adequate resources. Third, as argued by Carr, successful IT investment comes down to successful management processes and practices, not necessarily those who invest in IT. ${ }^{150}$ This is a critical suggestion for hospitals which need to assess their IT evaluation resources allocation processes carefully. 


\section{Conclusions and Implications}

\subsection{Summary of key research findings}

This study examines the effects of several organizational drivers on the realization of $\mathrm{B} 2 \mathrm{~B}$ ecommerce benefits and, in the process, empirically validates a $\mathrm{B} 2 \mathrm{~B}$ e-commerce evaluation management model that will be of use to both researchers and practitioners. IT maturity was found to have a significant positive impact on the adoption of IT investment evaluation methodologies which, in turn, had a significant effect on the allocation of IT evaluation resources. The results also revealed that an accurate and complete user information requirements determination process was positively related to the allocation of IT evaluation resources. These, in turn, also had a significant positive

\subsection{Theoretical contributions}

The findings provide a number of implications for theory and practice. A key finding of this study is the mediating role played by the allocation of IT evaluation resources in the process of B2B e-commerce benefits realization (Figure 1). The results first highlight the importance of the level of IT maturity in supporting the use of IT investment evaluation methodologies. The level of IT maturity among Taiwanese hospitals was found to be a crucial factor in their ability to adopt an IT investment evaluation methodology or process. Both the adoption of IT investment evaluation methodologies and the user requirements determination process evaluation practices were found to be the main organizational factors to assist in enhancing Taiwanese hospitals' capability to allocate requisite IT evaluation resources in the process of realizing B2B e-commerce benefits.

In addition, previous research has argued that IT/B2B e-commerce investments do not always lead to benefits. $^{151,152,153}$ This study provides a theoretical explanation as to why. Due to the complementarity nature of these organizational drivers, they need to be managed together, not in isolation. Focusing on one driver of a strategic alignment and neglecting the other drivers will not lead to desirable performance effects. ${ }^{154}$ For example, IT investment evaluation methodologies and user information requirements determination processes have been found to have no direct influence on the realization of $\mathrm{B} 2 \mathrm{~B}$ e-commerce benefits. It has to be used in conjunction with the allocation of sufficient requisite IT evaluation resources to have any significant impact on B2B e-commerce benefits. Hence, it is critical for senior hospital IT executives to carefully assess their B2B e-commerce investments and ensure that the required level of IT maturity, the adoption of IT investment evaluation methodologies and user information requirements determination processes, and the level of IT evaluation resources allocated are appropriate in the process of realizing B2B e-commerce benefits.

\subsection{Implications for practice}

Based on our findings senior hospital IT executives should focus on making IT an integral part of their business strategy. They should conduct an assessment of their IT and B2B e-commerce investments so that features and benefits can be readily identified and matched with the strategic vision of the hospital. Moreover, investments in IT/B2B e-commerce have allowed both large and small organizations to target customers at a much lower cost. Therefore, hospitals senior executives need to make more informed decisions on how to invest in various types of IT/B2B initiatives and systems in order to maximize their profitability and growth through building relationship with their customers and suppliers. For example, through the participation of the virtual or online communities, intensive public health promotion campaigns, the level of awareness and positive image of the products and services offered by hospitals and other healthcare organizations can be increased for both the existing and potential healthcare suppliers and customers. $^{155,156,157,158}$ However, these activities and strategies need to be implemented with good faith without resorting deceptive tactics as adopted by some healthcare organizations in the past. ${ }^{159,160,161,162}$

\subsection{Limitations and future research directions}

Some limitations have to be acknowledged in this study. The choice of constructs which may not fully capture the complex nature of the B2B/IT investment evaluation process of the business environment in which Taiwanese hospitals operate. Equally, benefits and organizational drivers such as user requirements determination process and IT maturity do not remain static, particularly during the different stages of an IT 
project life cycle. Further research can take a longitudinal approach as the drivers and the approach to managing B2B/IT benefits and evaluation are likely to change over time.

\section{Acknowledgements}

We would like to thank Sheng-Hsiang Hung who assisted in collecting some of the data for this study.

\section{References}

1. A. K. Alsaad, Mohamad, R., and Ismail, N. A. The Moderating Role of Power Exercise in B2B E-commerce Adoption Decision. Procedia-Social and Behavioral Sciences, 130, 515-523 (2014).

2. C. Lin, Y. Huang, and R. Stockdale, Developing a B2B Website Effectiveness Model for SMEs, Internet Research, 21(3), 304-325 (2011).

3. P. Humphreys, Fynes, B., and Wiengarten, F. Creating Business Value Through e-Business in the Supply Chain. Handbook of Strategic e-Business Management, 237-254, Springer Berlin Heidelberg (2014).

4. L. B. Oh, Teo, H. H., and Sambamurthy, V. The Effects of Retail Channel Integration Through the Use of Information Technologies on Firm Performance. Journal of Operations Management, 30(5), 368-381 (2012).

5. M. S. Bexci and Subramani, R. Dissemination and Updation of Advanced Surgical Knowledge Using Video Conferencing Technology for Surgeons in INDIA-A Case Study of Ortho One Hospital Knee Programme. International Journal of Management Science and Technology, 1(2) (2013).

6. R. G. Cady and Finkelstein, S. M. Mixed-Methods Approach for Measuring the Impact of Video Telehealth on Outpatient Clinic Triage Nurse Workflow. Computers Informatics Nursing, 31(9), 439-449 (2013).

7. S. Saleh, Larsen, J. P., Bergsåker-Aspøy, J., and Grundt, H. Re-admissions to Hospital and Patient Satisfaction among Patients with Chronic Obstructive Pulmonary Disease after Telemedicine Video Consultation-a Retrospective Pilot Study. Multidisciplinary Respiratory Medicine, 9(1), 6 (2014).

8. III, B2B E-Commerce Survey Study, 2009, Institute for Information Industry, Taiwan, http://web.iii.org.tw/ (2010).

9. Y. Huang, H. Chung, and C. Lin, R\&D Sourcing Strategies: Determinants and Consequences, Technovation: The International Journal of
Technological Innovation, Entrepreneurship and Technology Management, 29(3),155-169 (2009).

10. L. T. Chen, Dynamic Supply Chain Coordination Under Consignment and Vendor-managed Inventory in Retailercentric B2B Electronic Markets. Industrial Marketing Management, 42(4), 518-531 (2013).

11. K. Lin, C. Lin, and W. Kuo, The Adoption and Management of Interactive Digital TV Commerce in Taiwan, International Journal of Management, 25(2), 287-299 (2008).

12. W. K. Chong, Tadjouddine, E. M., Shafaghi, M., and Tan, B. L. Automated Mechanism Design for B2B eCommerce Models. International Journal of Trade, Economics and Finance, 2(1), 87-92 (2011)..

13. C. Standing, A. Guilfoyle, C. Lin and P. E. D. Love. The Attribution of Success and Failure in IT Projects, Industrial Management and Data Systems, 106(8), 11481165 (2006).

14. S. Hoejmose, Brammer, S., and Millington, A. "Green" Supply Chain Management: The Role of Trust and Top Management in B2B and B2C Markets. Industrial Marketing Management, 41(4), 609-620 (2012).

15. Y. Huang, C. Lin and H. Lin, Techno-economic Effect of R\&D Outsourcing Strategy for Small and Medium-sized Enterprises: A Resource-Based Viewpoint, International Journal of Innovation and Incubation, 2(1), 1-22 (2005).

16. Y. Liu, Y. Huang, and C. Lin. Organizational Factors' Effects on The Success of E-Learning System and Organizational Benefits - An Empirical Study in Taiwan, International Review of Research in Open and Distance Learning, 13(4), 130-151 (2012).

17. K. Lin and C. Lin Evaluating the Decision to Adopt RFID Systems Using Analytic Hierarchy Process, The Journal of American Academy of Business, Cambridge, 11(1), $72-78$ (2007).

18. J. Lee, McCullough, J. S., and Town, R. J. The Impact of Health Information Technology on Hospital Productivity. The RAND Journal of Economics, 44(3), 545-568 (2013).

19. L. Wu, and Kuo, Y. ZA Balanced Scorecard Approach in Assessing IT Value in Healthcare Sector: An Empirical Examination. Journal of Medical Systems, 36(6), 35833596 . (2012).

20. Z. Ji, and Ye, J. Export or Not with Productivity Heterogeneous Enterprises? Empirical Evidence from China's Bio-Pharmaceutical Industry. International Business Research, 6(4), 164-169 (2013).

21. L. Lapointe, Mignerat, M., and Vedel, I. The IT 
Productivity Paradox in Health: A Stakeholder's Perspective. International Journal of Medical Informatics, 80(2), 102-115 (2011).

22. R. Meyer, and Degoulet, P. Choosing the right amount of healthcare information technologies investments. International journal of medical informatics, 79(4), 225231 (2010).

23. E. Brynjolfsson and Hitt, L. M. Computing Productivity: Firm-Level Evidence, The Review of Economics and Statistics. 85(4), 793-808 (2003).

24. T. A. Byrd, Lewis, B.R., and Bryan, R.W. The Leveraging Influence of Strategic Alignment on IT Investment: An Empirical Examination. Information and Management, 43, 308-321 (2006).

25. Q. Hu and Quan, J. J. Evaluating the Impact of IT Investments on Productivity: A Causal Analysis at Industry Level. International Journal of Information Management, 5(1), 39-53 (2005).

26. C. Subramaniam, \& Shaw, M. J. A study of the value and impact of B2B e-commerce: the case of web-based procurement. International Journal of Electronic Commerce, 6, 19-40 (2002).

27. G. Hackbarth and Kettinger WJ Strategic Aspirations for Net-Enabled Business. European Journal of Information Systems, 13(4), 273-285 (2004).

28. C. Lin, and Y. Huang, An Integrated Framework for Managing eCRM Evaluation Process, International Journal of Electronic Business, 5(4), 340-359 (2007).

29. N. Melville, Kraemer, K. and Gurbaxani, V. Review: Information Technology and Organizational Performance: An integrative Model of IT Business Value, MIS Quarterly, 28(2), 283-322 (2004).

30. K. Hogg, Chilcott, P., Nolan, M., and Srinivasan, B. An evaluation of Web services in the design of a B2B application. In Proceedings of the 27th Australasian Conference on Computer Science-Volume 26 (pp. 331340). Australian Computer Society, Inc (2004).

31. F. Farrelly, Quester, P., and Greyser, S. A. Defending the co-branding benefits of sponsorship B2B partnerships: The case of ambush marketing. Journal of Advertising Research, 45(03), 339-348 (2005).

32. C. Lin, Y. Huang, and S. Tseng. A Study of Planning and Implementation Stages in Electronic Commerce Adoption and Evaluation: The Case of Australian SMEs, Contemporary Management Research, 3(1), 83-100 (2007).

33. M. Chiasson, Reddy, M., Kaplan, B., and Davidson, E. Expanding Multi-disciplinary Approaches to Healthcare
Information Technologies: What does Information Systems offer Medical Informatics, International Journal of Medical Informatics, 76s, s89-s97 (2007).

34. A. J. Cullen and Taylor, M. Critical Success Factors for B2B E-commerce use within the UK NHS Pharmaceutical Supply Chain, International Journal of Operations and Production Management, 29(11), 11561185 (2009).

35. J. Van Akkeren and Rowlands, B. An Epidemic of Pain in an Australian Radiology Practice, European Journal of Information Systems, 16(6): 695-711 (2007).

36. C. Lin, Examining the Factors Affecting the Evaluation and Adoption of IT Investments in Pharmaceutical Organizations, International Technology Management Review, 3(2), 71-79 (2013).

37. R. Rupert, Strategic Marketing in the Ehealth Ear: Who Will Own the Provider's Networked Desktop?", International Journal of Medical Marketing, 2(2): 111 (2002).

38. L. Lerer, E-business in the Pharmaceutical Industry, International Journal of Medical Marketing, 3(1), 69 (2002).

39. P. Joyce, Green, R. and Winch, G. A New Construct for Visualising and Designing E-Fulfilment Systems for Quality Healthcare Delivery, The TQM Magazine, 18(6): 638-51 (2006).

40. R. D. Banker, Davis, G.B., and Slaughter, S.A. Software Development Practices, Software Complexity, and Software Maintenance Performance: A Field Study. Management Science 44, 433-450 (1998).

41. C. Standing and C. Lin, Organizational Evaluation of the Benefits, Constraints and Satisfaction with Business-ToBusiness Electronic Commerce, International Journal of Electronic Commerce, 11(3), 107-153 (2007).

42. P. P. Tallon, Kraemer, K. L. and Gurbaxani, V. Executives' Perceptions of the Business Value of Information Technology: A Process-Oriented Approach, Journal of Management Information Systems, 16(4), 145173 (2000).

43. C. Lin, Y. Huang, and M. Cheng, The Adoption of IS/IT Investment Evaluation and Benefits Realization Methodologies in Service Organizations: IT Maturity Paths and Framework, Contemporary Management Research, 3(2), 173-194 (2007).

44. E. Gummesson and Mele, C. Marketing as value cocreation through network interaction and resource integration. Journal of Business Market Management, 4(4), 181-198 (2010). 
45. P. E. D. Love, Z. Irani, C. Standing, C. Lin and J. Burn, The Enigma of Evaluation: Benefits, Costs and Risks of IT in Small-Medium Sized Enterprises, Information and Management, 42(7), 947-964 (2005).

46. H. Tsao, K. Lin and C. Lin, An Investigation of Critical Success Factors in the Adoption of B2BEC by Taiwanese Companies, The Journal of American Academy of Business, Cambridge, 5(1/2), 198-202 (2004).

47. C. Lin, G. Pervan, K. Lin, and H. Tsao An Investigation into Business-to-Business Electronic Commerce Organizations, Journal of Research and Practice in Information Technology, 40(1), 3-18 (2008).

48. N. F. Doherty, Ashurst, C., and Peppard, J. Factors Affecting the Successful Realisation of Benefits from Systems Development Projects: Findings from Three Case Studies. Journal of Information Technology, 27(1), 1-16 (2012).

49. M. Johnson, Critical Success Factors for B2B e-Markets: A Strategic Fit Perspective. Marketing Intelligence and Planning, 31(6), 698-727 (2013).

50. C. Lin, K. Lin, Y. Huang, and G. Jalleh, The Fit Between Organizational B2B E-commerce Policy, IT Maturity and Evaluation Practices on B2B E-commerce Performance in Australian Healthcare Organizations, African Journal of Business Management, 5(5), 1983-2005 (2011).

51. I. Sila, Factors Affecting the Adoption of B2B Ecommerce Technologies. Electronic Commerce Research, 13(2), 199-236 (2013)..

52. S. Thatcher, S., Foster, W., and Zhu, L. B2B e-commerce adoption decisions in Taiwan: The interaction of cultural and other institutional factors. Electronic Commerce Research and Applications, 5(2), 92-104 (2006).

53. L. Zhu, L., and Thatcher, S. M. The institutional environment for B2B e-commerce adoption: a quantitative study of electronics and textiles firms in Greater China and the USA. International journal of networking and virtual organisations, 4(1), 92-104 (2007).

54. C. Lin, K. Lin, Y. Huang, and Y. Liu, A Comparative Study of IT Outsourcing Management in Australia and Taiwan, Journal of International Management Studies, 2(2), 29-39 (2007).

55. A. M. Chircu, and Kauffman, R. J. Limits to Value in Electronic Commerce-related IT Investments. Journal of Management Information Systems 17(2), 59-80 (2000).

56. M. Chan, Pang, V., Bunker, D., and Smith, S. What Do We Mean by E-Procurement?-A Private Hospital Perspective in Australia, The Tenth Pacific Asia
Conference on Information Systems (PACIS 2006), Kuala Lumpur, Malaysia, July 6-9, pp1353-1361 (2006).

57. R. Kalakota, and Whinston, A. B. Frontiers of Electronic Commerce. Addison-Wesley, Reading, MA, USA (1996).

58. N. Karagozoglu, and Lindell, M. Electronic Commerce Strategy, Operations, and Performance in Small and Medium-sized Enterprises, Journal of Small Business and Enterprise Development, 1(3): 290-301 (2004).

59. R. Montealegre, A Process Model Of Capability Development: Lessons from the Electronic Commerce Strategy at Bolsa de Valores de Guayaquil, Organization Science, 13(5): 514-531 (2002).

60. C. J. Chao, C. Lin, K. Lin, C. L. Shen, and C. H. Wang, Using the Analytic Hierarchy Process Methodology to Assess the Drivers Affecting the Implementation of Interactive Digital Television as a Commerce Platform, International Journal of Wireless Networks and Broadband Technologies. 2(3), 42-51 (2012).

61. C. Lin, Y. Huang, Y. Liu, and G. Jalleh, Benefits Realization of B2B e-Commerce in Hospitals and the Connection with IS Capability, IS Expertise, Resources Allocation, and Top Management Support, Electronic Commerce Studies, 11(1), 101-122 (2013).

62. B. G. Hope, Hermanek, M., Schlemmer, C., and Huff, S.

L. Critical Success Factors in the Development of Business-to-business Electronic Commerce, Journal of Information Technology - Case and Applications, 3, 7-33 (2001).

63. S. Standing, C. Standing, and C. Lin, A Framework for Managing Knowledge in Strategic Alliances in the Biotechnology Sector, Systems Research and Behavioral Science, 25(6), 783-796 (2008).

64. R. Suomi, Tahkapaa, J., and Holm, J. Organizational and Information System Metaphors in the Health Care Sector - From Harmonized Value Chain to Realistic Market Models, The 9th European Conference on Information Systems, Bled, Slovenia, June 27-29 (2001).

65. R. E. McGaughey, Benchmarking Business-to-business Electronic Commerce, Benchmarking: An International Journal, 9(5), 471-484 (2002).

66. Y. Huang, I. Phau, C. Lin, C., H. Chung, and K. Lin, Allocentrism and Consumer Ethnocentrism: Social Identity on Purchase Intention, Social Behavior and Personality: An International Journal, 36(8), 1097-1110 (2008).

67. Y. Huang, I. Phau, and C. Lin, Effects of Animosity and Allocentrism on Consumer Ethnocentrism: Social 
Identity on Consumer Willingness to Purchase, Asia Pacific Management Review, 15(3), 359-376 (2010).

68. M. Cutler and Sterne, J. E-Metrics: Business Metrics for the New Economy, NetGenesis, Source: [On-Line]: http://www.netgen.com/emetrics/ (2000).

69. C.Lin, Y. Huang, G. Jalleh, Y. Liu, and M. Tung, An Exploratory Study of Factors Affecting Adoption and Implementation of B2B E-Commerce in Australian Health Care Organizations, International Journal of Electronic Commerce Studies, 1(2), 77-96 (2010).

70. W. Piotrowicz, and Irani, Z. Analysing B2B Electronic Procurement Benefits: Information Systems Perspective, Journal of Enterprise Information Management, 23(4), 559-579 (2010).

71. M. J. Van der Meijden, Tange, H.J., Troost, J., and Hasman, A. Determinants of success of inpatient clinical information systems: a literature review, Journal of the American Medical Informatics Association, 10(3): 235243 (2003).

72. M. M. Yusof, Kuljis, J., Papazafeiropoulou, A., and Stergioulas, L. K. An Evaluation Framework for Health Information Systems: Human, Organization and Technology-fit Factors (HOT-fit): International Journal of Medical Informatics, 77(6): 386-398 (2008).

73. M. M. Yusof, Papazafeiropoulou, A., Paul, R. J., and Stergioulas, L. K. Investigating Evaluation Frameworks for Health Information Systems, International Journal of Medical Informatics, 77(6): 377-385 (2008).

74. C. Lin, K. Lin, Y. Huang, and W. Kuo, Evaluation of Electronic Customer Relationship Management: The Critical Success Factors, The Business Review, Cambridge, 6(2), 206-212 (2006).

75. F. Gremy Fessler, J. M, and Bonnin, M. Information Systems Evaluation and Subjectivity, International Journal of Medical Informatics, 56, 13-23 (1999).

76. J. C. Wyatt, and Wyatt, S. M. When and how to evaluate health information systems? International Journal of Medical Informatics, 69(2-3): 251-259 (2003).

77. Y. Huang, I. Phau, and C. Lin, Consumer Animosity, Economic Hardship, and Normative Influence: How Do They Affect Consumer's Purchase Intention?, European Journal of Marketing, 44(7/8), 909-937 (2010).

78. C. Lin, Y. Huang, and J. Burn, Realising B2B eCommerce Benefits: The Link with IT Maturity, Evaluation Practices, and B2B e-Commerce Adoption Readiness, European Journal of Information Systems, 16(6), 806-819 (2007).
79. Y. Zhuang, Does Electronic Business Create Value For Firms? An Organizational Innovation Perspective, Journal of Electronic Commerce Research, 6(2), 146-159 (2005).

80. Y. Liu, and C. Lin, How Are Public Sector Organizations Assessing their IT Investments and Benefits - An Understanding of Issues For Benchmarking, International Journal of Advanced Information Technologies, 2(2), 86-100 (2008).

81. A. Kazanjian, and Green, C.J. Beyond effectiveness: the evaluation of information systems using a comprehensive health technology assessment framework, Computers in Biology and Medicine, 32: 165-177 (2002).

82. W. W. Stead, Haynes, R. B., Fuller, S., Friedman, C. P., Travis, L. E., Beck, J. R., Fenichel, C. H., Chandrasekaran, B., Buchanan, B. G., Abola, E.E. Designing medical informatics research and libraryresource projects to increase what is learned, Journal of American Medical Informatics Association, 1(1), 28-33 (1994).

83. B. Kaplan, Organizational evaluation of medical information resources, in Evaluation Methods in Medical Informatics, Springer-Verlag, New York, 255-280 (1997).

84. E. Ammenwerth, Brender, J., Nykanen, P., Prokosch, H., Rigby, M., and Talmon, J. HIS-EVAL workshop participants. Visions and strategies to improve evaluation of health information systems: reflections and lessons based on the HIS-EVAL workshop in Innsbruck, International Journal of Medical Informatics, 73(6): 479491 (2004).

85. R. D. Galliers, and Sutherland, A. R. Information Systems Management and Strategy Formulation: The 'Stages of Growth' Model Revisited. Journal of Information Systems, 1(1), 89-114 (1991).

86. C. Lin, An Investigation of the Process of IS/IT Investment Evaluation and Benefits Realisation in Large Australian Organisations, $\mathrm{PhD}$ Thesis, Curtin University of Technology, Perth, Western Australia, Source: [OnLine] http://adt.curtin.edu.au/theses/available/adtWCU20030826.094151/, pp1-427 (2002).

87. J. Y. L. Thong, An Integrated Model of Implementation Systems Adoption in Small Businesses. Journal of Management Information Systems, 15(4), 187-214 (1999).

88. C. Lin, Y. Huang, and G. Jalleh, Improving Alliance Satisfaction: The Resource Alignment of IT Competency in Small Healthcare Centers, International Technology Management Review, 1(2), 25-42 (2008). 
89. T. Auer and Reponen, T. Information System Strategy Formation Embedded into a Continuous Organizational Learning Process. Information Resource Management Journal, 10, 32-43 (1997).

90. C. Lin, and G. Pervan, Realising the Benefits of IS/IT Investments in Australian Organisations, Proceedings of the Eleventh Australasian Conference on Information Systems (ACIS 2000), Brisbane, Australia, 6-8 December, pp1-13 (2000).

91. H.A. Akkermans, and van der Horst, H. Managing IT Infrastructure Standardisation in the Networked Manufacturing Firm, International Journal of Production Economics, 75: 213-228 (2002).

92. R. G. Schuh, and Leviton, L. C. A Framework to Assess the Development and Capacity of Non-profit Agencies, Evaluation and Program Planning, 29(2), 171-179 (2006).

93. J. J. Jiang, Klein, G. and Pick, R. A. The Impact of IS Department Organizational Environments upon Project Team Performances, Information and Management, 40(3), 213-220 (2003).

94. C. Lin, G. Pervan, and D. McDermid, Research on IS/IT Investment Evaluation and Benefits Realization in Australia, In Van Grembergen, W. (Ed.), Information Systems Evaluation Management, Chapter 15, IRM Press, Hershey, USA, 244-254 (2002).

95. G. J. Browne, and Ramesh, V. Improving Information Requirements Determination: A Cognitive Perspective, Information and Management, 39, 625-645 (2002).

96. J. I. Westbrook, Braithwaite, J., Georgiou, A., Ampt, A., Creswick, N., Coiera, E., and Iedema, R. Multimethod Evaluation of Information and Communication Technologies in Health in the Context of Wicked Problems and Sociotechnical Theory, Journal of American Medical Informatics Association, 14(6), 746755 (2007).

97. C. Lin, G. Pervan, and D. McDermid, IS/IT Investment Evaluation and Benefits Realization Issues in Australia, Journal of Research and Practice in Information Technology, 37(3), 235-251 (2005).

98. R. M. Grant, The Resource-Based Theory of Competitive Advantage: Implications for Strategy Formulation. California Management Review, Spring, 114-135 (1991).

99. R. Amit and Schoemaker, P. Strategic assets and organizational rent. Strategic Management Journal, 14, 33-46 (1993).
100. J. B. Barney, Wright, M.; Ketchen Jr., D.J. The resourcebased view of the firm: Ten years after 1991. Journal of Management, 27(6), 625-641 (2001).

101. W. Kuo, C. Lin, G. Hsu, and Y. Huang, An Empirical Study of Resource Contribution in SMEs Alliance, Journal of Global Business Management, 2(2), 103-111 (2006).

102. C. Lin, and Y. Huang, A Model of IT Evaluation Management: Organizational Characteristics, IT Evaluation Methodologies, and B2BEC Benefits, Lecture Notes in Computer Science, 149-158 (2007).

103. V. Karthik, and Kumar, S. Investigating 'Degree of Adoption' Effects on e-procurement Benefits. International Journal of Procurement Management, 6(2), 211-234 (2013).

104. K. K. Kim, and Umanath, N. S. Information Transfer in B2B Procurement: An Empirical Analysis and Measurement, Information and Management, 42(6), 813828 (2005).

105. I. Ayal and Rothberg, R. Strategic control of R\&D resource allocations in diversified businesses. Journal of Product Innovation Management, 3(4), 238-50 (1986).

106. H. Eilat, Golany, B., and Shtub, A. Constructing and Evaluating Balanced Portfolios of R\&D Projects with Interactions: A DEA Based Methodology. European Journal of Operational Research 172, 1018-1039 (2006).

107. Y. Huang, C. Lin, Y. Liu, and M. Tung, The Effects of IT Resource Alignment and Organizational Dynamism on Alliance Performance in Hemodialysis Centers, International Technology Management Review, 3(2), 105-115 (2013).

108. L. M. Kern, Dhopeshwarkar, R., Barrón, Y., Wilcox, A., Pincus, H., and Kaushal, R. Measuring the Effects of Health Information Technology on Quality of Care: A Novel Set of Proposed Metrics for Electronic Quality Reporting. Joint Commission Journal on Quality and Patient Safety, 35(7), 359-369 (2009).

109. C. Lin, and G. Pervan, IS/IT Investment Evaluation and Benefits Realisation Issues in a Government Organisation, Proceedings of the Twelfth Australasian Conference on Information Systems (ACIS 2001), Coffs Harbour, NSW, Australia, 5-7 December, pp379-386 (2001).

110. G. Ooi, and Soh, C. Developing an Activity-based Costing Approach for System Development and Implementation. Database for Advances in Information Systems, 34, 54-71 (2003). 
111. B. Liu, Research on Logistics Distribution Center Location Model and Evaluation Under Electronic Commerce. JDCTA: International Journal of Digital Content Technology and its Applications, 7(2), 216-222 (2013).

112. J. S. Hsu, Lin, T., Zheng, G., and Hung, Y. Users as knowledge co-producers in the information system development project, International Journal of Project Management, 30(1), 27-36 (2012).

113. J. Y. Liu, Chen, H., Chen, C., and Sheu, T. S. Relationships among Interpersonal Conflict, Requirements Uncertainty, and Software Project Performance, International Journal of Project Management, 29(5), 547-556 (2011).

114. I. Wu, and Shen, Y. A Model for Exploring the Impact of Purchasing Strategies on User Requirements determination of e-SRM, Information and Management, 43, 411-422 (2006).

115. T. Gorschek, Svahnberg, M., Borg, A., Loconsole, A., and Sandahl, K. A controlled empirical evaluation of a requirements abstraction model, Information and Software Technology, 49(7), 790-805 (2007).

116. M. Lee, and Jones, A. M. How Did Dentists Respond to the Introduction of Global Budgets in Taiwan? An Evaluation Using Individual Panel Data, International Journal of Health Care Finance \& Economics. 4(4), 307326 (2004).

117. D. Shapiro, Examining Taiwan's hospitals, Topics, American Chamber of Commerce in Taipei, 39(3) (2009).

118. THRF, Hospital Finance: The Financial Supervision for the Health Institutions in Taiwan, Taiwan Healthcare Reform Foundation, Taipei Taiwan (2011).

119. C. Lin, and Y. Huang, Key Factors Affecting the B2B ECommerce Evaluation and Outsourcing Practices in Australian and Taiwanese Hospitals, International Technology Management Review, 3(1), 22-41 (2013).

120. K. M. Eisenhardt, Building Theories From Case Study Research, Academy of Management Review, 14(4), 532550 (1989).

121. J. Mingers, Combining IS Research Methods: Towards a Pluralist Methodology', Information Systems Research, Vol. 12, pp. 240-259, (2001).

122. D. Remenyi,and Williams, B., The Nature of Research: Qualitative or Quantitative, Narrative or Paradigmatic?" Information Systems Journal, 6, 131-146, (1996).

123. C. Lin, G. Pervan, and D. McDermid, Issues and Recommendations in Evaluating and Managing the
Benefits of Public Sector IS/IT Outsourcing, Information Technology and People, 20(2), 161-183 (2007).

124. M. B. Miles, and Huberman, A.M. Qualitative Data Analysis: An Expanded Sourcebook, Sage Publications, California (1994).

125. R. K. Yin, Case Study Research, Design and Methods, 3rd Ed., Newbury Park, Sage Publications (2002).

126. B. W. Keats, and Bracker, J.S. Toward a theory of small firm performance: a conceptual model, American Journal of Small Business, 12(4), 41-58 (1988).

127. J.S. Armstrong and Overton, T. Estimating Nonresponse Bias in Mail Surveys. Journal of Marketing Research, 14 August, 396-402 (1977).

128. J. C. Nunnally, Psychometric Theory, McGraw-Hill, New York (1978).

129. J. Ward, Taylor, P. and Bond, P. Evaluation and Realisation of IS/IT Benefits: An Empirical Study of Current Practice, European Journal of Information Systems, 4(4), 214-225 (1996).

130. C. Lin, and G. Pervan, The Practice of IS/IT Benefits Management in Large Australian Organizations, Information and Management, 41(1), 13-24 (2003).

131. J. Ward, and Daniel, E. Benefits Management: Delivering Value from IS and IT Investments, John Wiley and Sons Ltd, Chichester, UK (2006).

132. K. Lin, C. Lin, and H. Tsao IS/IT Investment Evaluation and Benefit Realization Practices in Taiwanese SMEs, Journal of Information Science and Technology, 2(4), 4471 (2005).

133. J. W. Moody, Blanton, J. E., and Cheney, P. H. A Theoretically Grounded Approach to Assist Memory Recall during Information Requirements Determination, Journal of Management Information Systems, 15(1), 79-98 (1998).

134. C. Lin, and K. Lin, A Study of Information Requirement Determination Process of an Executive Information System, In Adam, F. and Humphreys, P. (Eds.), Encyclopedia of Decision Making and Decision Support Technologies, Chapter 91, Hershey, USA, 807-813 (2008).

135. Z. Kao, The Impacts of the Importance Attachment of IT for Enterprises to Adopt the Investment Evaluation and Benefit Realization Methodologies, Master Thesis, National Kaohsiung First University of Science and Technology, Taiwan (2008).

136. T.S.H. Teo and Ranganathan, C. Adopters and nonadopters of business-to-business electronic commerce in 
Singapore, Information and Management, 42(1), 89-102 (2004).

137. N. Venkatraman, and Ramanujam, V. Measurement of Business Economic Performance: An Examination of Method Convergence. Journal of Management, 13(1), 109-122 (1987).

138. R. T. Watson, Influences on the IS manager's perceptions of key issues: information scanning and the relationship with the CEO”, MIS Quarterly, 14(2), 217-231 (1990).

139. A. C. Boynton, Zmud, R. W., and Jacobs, G. C. The Influence of IT Management Practice on IT Use in Large Organizations, MIS Quarterly, 18(3): 299-318 (1994).

140. V. Grover, Teng, J., Segar, A.H. and Fiedler, K. The influence of information technology diffusion and business process change on perceived productivity: the IS executive's perspective, Information and Management, 34(3), 141-159 (1998).

141. W. Lin, Y. Huang, and C. Lin, Information Technology Executives' View on the Factors that Influence the Success of Information Technology Investments, The Journal of Human Resource and Adult Learning, 3(1), 41-52 (2007).

142. K. G. Jöreskog and Sörbom, D. LISREL 8: A Guide to the Program and Applications, SPSS, Chicago (1993).

143. G. A. Churchill, A paradigm for developing better measures of marketing constructs, Journal of Marketing Research , 16(1), 64-73 (1979).

144. J. F. Hair, W. C. Black, B. J., R. E.Anderson, R. L. Tatham, Multivariate Data Analysis, Pearson Education, Upper Saddle River, NJ (2006).

145. C. Fornell, and D.F. Larcker Evaluating structural equation models with unobservable variables and measurement error, Journal of Marketing Research, 18(1), 39-50 (1981).

146. M. M. Espinoza, Assessing the cross-cultural applicability of a service quality measure: a comparative study between Quebec and Peru", International Journal of Service Industry Management, 10, 449-68 (1999).

147. J. Hulland, Chow, Y. H., and Lam, S. Use of Causal Models in Marketing Research: A Review, International Journal of Research in Marketing, 13(2), 181-197 (1996).

148. W. W. Chin, The Partial Least Squares Approach to Structural Equation Modeling, In Modern Methods for Business Research, G. A. Marcoulides (Ed.), Lawrence Erlbaum, Mahway, New Jersey, 295-336 (1998).

149. S. Sharma, Applied Multivariate Techniques, John Wiley and Sons, New York (1996).
150. N. G. Carr, IT doesn't matter, Harvard Business Review, 81(5), 41-49 (2003).

151. C. Lin, Y. Huang, M. Cheng, and W. Lin Effects of Information Technology Maturity on the Adoption of Investment Evaluation Methodologies: A Survey of Large Australian Organizations, International Journal of Management, 24(4), 697-711 (2007).

152. K. Osei-Bryson, and Ko, M. Exploring the Relationship Between Information Technology Investments and Firm Performance Using Regression Splines Analysis, Information and Management, 42(1), 1-13 (2004).

153. M. D. Thatcher and Pingry, D. E. Understanding the Business Value of Information Technology Investments: Theoretical Evidence from Alternative Market and Cost Structure, Journal of Management Information Systems, 21(2), 61-85 (2004).

154. G. G. Grant, Strategic alignment and enterprise systems implementation: the case of Metalco, Journal of Information Technology, 18(3), 159-175 (2003).

155. G. Jalleh, R. J. Donovan, T. Slevin, and C. Lin, Efficacy of Breast Cancer Appeals for Promoting Physical Activity, Journal of Cancer Education,24(1), 33-35 (2009).

156. K. Economo, S. Stewart, D. Sullivan, G. Jalleh, O. Carter, C. Lin, The Importance of Public Education Campaigns in Raising Awareness and Support for Smoke-free Car Legislation in Western Australia, Australian and New Zealand Journal of Public Health, 34(1), 92-93 (2010).

157. G. Jalleh, R. J. Donovan, C. Lin, T. Slevin, C. Clayforth, S. Pratt, and M. Ledger Beliefs about bowel cancer among the target group for the National Bowel Cancer Screening Program in Australia, Australian and New Zealand Journal of Public Health, 34(2), 187-192 (2010).

158. C. Lin, C. Standing, and Y. Liu, A Model to Develop Effective Virtual Teams, Decision Support Systems, 45(4), 1031-1045 (2008).

159. N. Heydon, K. S. Kennington, G. Jalleh, and C. Lin Western Australian Smokers' Strongly Support Regulations on the Use of Chemicals and Additives in Cigarettes, Tobacco Control, 21(3), 381-382 (2012).

160. E. Strout, To tell the truth. Sales and Marketing Management, 154(7), 40-47 (2002).

161. G. Jalleh, R. J. Donovan, C. Lin, and T. Slevin, Changing Perceptions of Solaria and Cancer Risk: The Role of the Media, Medical Journal of Australia, 188(12), 735-735 (2008). 
162. R. Johnson, G. Jalleh, I. S. Pratt, R. J. Donovan, C. Lin, C. Saunders, and T. Slevin, Online advertising by three commercial breast imaging services: Message takeout and effectiveness. The Breast, 22(5), pp780-786 (2013).

Published by Atlantis Press

Copyright: the authors 